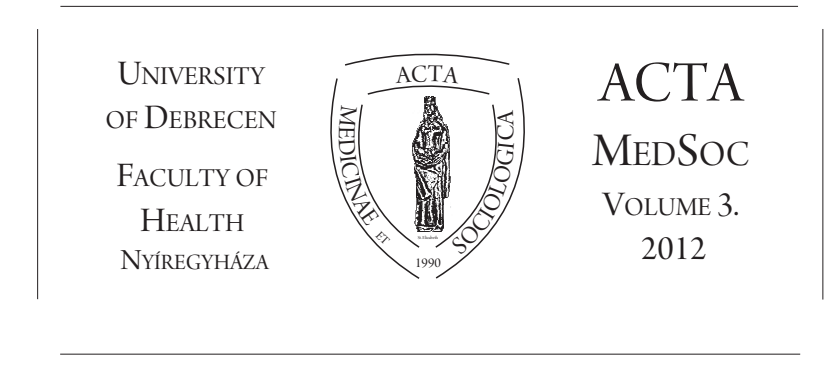

\title{
Az utolsó vacsora az Újszövetségi Szentírásban
}

\author{
Gánicz Endre
}

Szent Atanáz Görög Katolikus Hittudományi Főiskola, Szentírástudományi Tanszék

\begin{abstract}
The Last Supper in the New Testament.
The narrative of the Last Supper presents two important events: the statement of the tradition of Jesus and the foundation of the Eucharist. Aside from the fact whether the Last Supper coincides with the Jewish paschal meal or not, it is certain, that it is the paschal fest of Jesus Christ of his own. During the Supper the twelve apostles, who were the closest to Him, in the form of bread and wine actually took His body and blood, because the word of the God is powerful. Jesus enunciated that He voluntarily offers his life for everybody in the name of the New Testament, which ensures everybody the possibility of salvation.
\end{abstract}

Keywords: Last Supper, Jesus Christ, sacrifice, love, New Testament

DOI: $10.19055 / \mathrm{ams} .2012 .3 / 4-5 / 6$

\section{Bevezetés}

Az utolsó vacsora fogalmát minden múvelt, akár nem hívô ember is ismeri, hiszen az általános múveltséghez hozzátartozik az is, hogy Jézus Krisztus életének fontosabb eseményeit ismerjük. Ha a Szentírás szövegét még nem is olvasta mindenki, a múvészek által a történelem során sokszor megjelenített eseményt az emberek túlnyomó többsége ismeri. A kiemelkedő alkotások közé tartozik Leonardo da Vinci Utolsó vacsora címú freskója, amely a Santa Maria delle Grazie kolostor refektóriumának falát díszíti 1498 óta. Ez a tanulmány arra hivatott, hogy az Újszövetségi 
Szentírás szövegén - azaz a múvészeket is inspiráló eredeti szövegen - keresztül, az utolsó vacsorára vonatkozó elbeszélés elemzése révén jobban megismerhessük az ott történteket illetve Jézus Krisztus személyét.

Az utolsó vacsora perikópáját mindhárom szinoptikus evangéliumban megtalálhatjuk. ${ }^{1}$ Ez az elbeszélés két részre osztható: Jézus elárulásának kijelentésére és az eucharisztia megalapítására. Jézus elárulásának története a negyedik evangéliumban, János evangéliumában is olvasható (Jn 13,2.21-30). Az eucharisztia megalapításakor elhangzott jézusi szavak a Korintusiakhoz írt elsố levélben (1Kor 11,23-25) - mint az erról szóló, legkorábban írásba foglalt tanúságtételben - szintén megtalálhatóak.

\section{Az utolsó vacsora szinoptikus elbeszélése}

\subsection{A Jézus elárulásának kijelentésérôl szóló rész}

Márk evangéliumát - mint a legkorábban írásba foglalt evangéliumot - alapul véve a következő elemek fordulnak elő az első részben (vö. Mk 14,17-21): este, tizenkettő, étel fogyasztása, Jézus kijelentése az elárulásáról, a tanítványok szomorúsága és kérdezősködése, Jézus válasza: „aki velem egyszerre márt a tálból”, Jézus kijelentése az áruló helyzetérôl. Máté szövegtöbblete (vö. Mt 26,20-25) ennek az első résznek a végén kiemeli Júdás kérdését: „Csak nem én vagyok az, Rabbi?”, valamint Jézus válaszát: „Te mondtad.” Lukácsnál (vö. Lk 22,21-23) valószínúleg a fordított sorrend miatt - elóbb található az eucharisztia alapítása csak aztán az elárulásról szóló versek - kimarad az este, a tizenkettő, az étel fogyasztásának megemlítése ebben a részben. Lukács szövege eltér még abban is, hogy nem Jézust kérdezik a tanítványok, hanem egymást.

Mk 14,17-21 egysége - megszokott módon - egy Márk evangélistától származó időmegjelöléssel és a „tizenkettô” megnevezésével kezdődik. Az evangélista számára az volt elsôdleges, hogy az esemény részeseiként a „tizenkettô” egészét, csoportját mutassa be, annak ellenére, hogy Jézus már kettőt elôre küldött. Valószínú az is, hogy a 20. versben az „egy a tizenkettő közül” kifejezés is Márk betoldása. Annak ellenére, hogy nagyon rövid ez az egység, egy két részre bontható, eredetileg önálló hagyomány meglétére következtethetünk. Az egyik (18-20 v.) az étkezés során elhangzott jézusi kijelentést tartalmazza, hogy elárulják, míg a másik (21. v.) átkot és figyelmeztetést tartalmaz. Az étkezés jelenetébe két nem Márktól, hanem az önálló hagyományt szerkesztôtól származó kiegészítés is került, amelyek összefüggésben állnak: maga az étkezés, illetve az ,aki velem eszik” a 18. versben. Ez utóbbi kicsit tompítja az eredetileg sokkal hangsúlyosabb, 20. versben található „aki egy tálba mártogat velem” sajátosságát.

\footnotetext{
${ }^{1}$ Vö. Mk 14,17-25; Mt 26,20-29; Lk 22,14-23
} 
A 21. v. három részre osztható: 1. az esemény leírása; 2. az eseményt kiváltó személy megátkozása; 3. az eseményt kiváltó személy megbüntetése. Ebben hasonlóságot találunk a Lk 17,1-ben található leírással. Ugyanakkor eltérés is mutatkozik az 1. pontban: Márknál ötvöződik az Emberfia szabad cselekedete az isteni elrendeléssel. Az Emberfia titulus az esemény leírásában a 2. szerkezeti részból származik, ami szintén megerôsíti azt, hogy a keresztény közösséget érdekelte Júdás helyzete.

A 14,17-21 egységében elóforduló, étkezésre utaló igék egyértelmúen arra helyezik a hangsúlyt, hogy az áruló egy bensóséges asztalközösség tagjai közül kerül ki. A szöveg - a szájhagyomány útján továbbadott perikópákra jellemzô módon nem tér ki a részletekre, de rögtön az étkezés leírásába kezd. Ami hangsúlyos, az nem más, mint Jézus szava, melyet kiemel a „bizony” kifejezés. A szövegkörnyezet alapján tudjuk csak azt állítani, hogy a húsvéti vacsoráról van szó, hiszen két tanítványát azért küldte eloore Jézus, hogy elookészítsék a termet a húsvéti vacsorához. $\mathrm{Az}$ anakeiszthai ige (jelentése: asztalhoz telepedni) önmagában még nem vonatkozik ünnepélyes étkezésre, annak ellenére, hogy Márk már csak egyszer, Heródes Antipász ünnepi lakomájára használja ezt az igét. Az elárulással kapcsolatban egyértelmú, hogy Jézus nyilvános múködéséhez koherensen nem a személyt, hanem a tettet ítéli el. A tettet tovább súlyosbítja azonban az, hogy egy olyan személy követi el, aki a Jézust követő tanítványok köréhez tartozik: „egy közületek”.

A Zsolt 41,10-re való utalás az asztalközösségrôl és annak megszúnésérôl szól, ami jelen helyzetben Jézus és a csupán körülírással jelölt Júdás között megtörtént. Épp az áruló személyének körülírása miatt a tanítványok reakciója a bizonytalanság és a szomorúság. A dogmatikai jelentéssel bíró isteni rendelkezés, amely nem figyelmeztetés akart lenni Júdás vagy a tanítványok számára, nem zárja ki a bưnt és az az iránti felelősséget. ${ }^{2}$ János apostol és evangélistával ellentétben (vö. Jn 13,26) Márk a még konkrétabb bejelentés során sem fedi fel az áruló személyét, késóbb a távozását sem írta le. Az asztalközösséget hangsúlyozó egy tál említése (eisz to hen trüblion) nem támasztja alá, de nem is cáfolja azt, hogy húsvéti vacsoráról lenne szó.

A 21. v. eufémizmussal fejezi ki az Emberfia halálát (hüpagein jelentése: elmenni), ami itt az Isten akaratának saját sorsára vonatkozó elfogadását jelenti. $\mathrm{Az}$ átok az Emberfiát kiszolgáltatóra vonatkozik, akit az átok formulákban általában ,az az ember” megjelöléssel illetnek. Márk szövegében az átok nem jelenti feltétlenül a kárhozat bejelentését.

A tizenkettô hangsúlyozása révén Márk evangélista arra akarja felhívni az olvasók figyelmét, hogy a Jézushoz való szoros tartozás sem mentheti meg az embert a hitehagyástól. ${ }^{3}$

Mt 26,20-25 leírása Márkén alapul, de a 25. v. szövegtöbbletéból ${ }^{4}$ is világosan látszik, hogy Júdás az, aki csupán Rabbinak, mesternek, tanítónak és nem Küri-

\footnotetext{
${ }^{2}$ Vö. Dér Katalin - Jorsits Attila, Beavatás Márk evangéliuma, Budapest 2011, 321.

${ }^{3}$ Vö. Gnilka, Joachim, Márk, Szeged 2000, 758-765.

${ }^{4}$ Mt 26,25: „Ekkor megszólalt Júdás, aki elárulta ôt: »Csak nem én vagyok az, Rabbi? « Ổ azt felelte neki: » Te mondtad.«"
} 
osznak, Úrnak nevezi Jézust, mint ahogy azt a többi 11 apostol teszi, akik ezáltal elismerték azt, hogy Jézus az életük Ura. ${ }^{5}$

Lk 22,21-23 a vacsora elbeszélése után mutatja be a másik két szinoptikussal szemben ${ }^{6}$, hogy Jézus és az áruló keze egy asztalon van. Nem az asztalközösséget kifejezố tálat említi, - mint Márk és Máté -, hanem csupán az asztalt, jobban elơtérbe állítva a tökéletes asztalközösség hiányát. ${ }^{7}$

János evangéliumában a lábmosásról és a búcsúbeszédekről szóló részben (vö. Jn 13,1-17,26) találhatjuk meg Jézus elárulásának kinyilatkoztatását, legkorábban a 13,2-ben, amely szintén étkezés során mutatja be, hogy az ördög sugallatára mit fog tenni iskarióti Júdás. A 13,18-val megtörténik a téma átvezetése, amelyet a 2130. vers között fejt ki az evangélista. A Jézus kiszolgáltatására (paradidómi ige) használt igét János használja a zsidókra és Pilátusra is, amikor azok a rómaiaknak illetve a hóhéroknak adták át Jézust. A Sátán kifejezés (vö. 27. v.) ebben a részben szerepel csupán a negyedik evangéliumban, de a „belemenni” (eiszerkhomai eisz) igével együtt sem akar a gonosz lélekre vonatkozó különleges tanítást adni. János szimbolikájának tudható be az a rövid megjegyzés: „Akkor pedig éjszaka volt” (vö 30. v.), amivel inkább a Júdásban végbemenố eseményeket akarta jelölni, mintsem puszta idô megállapítást végezni. A szeretett tanítvány - János evangélista - Péter kérdésére kérdezte meg Jézustól, hogy ki az áruló közülük, mire itt János evangéliumában Jézus egy bemártott falattal jelezte, ki az, aki elárulja. Mind a mai napig előfordul Keleten, hogy a házigazda étkezés közben egy bemártott, finom falatot tesz a vendég szájába. A tanítványok értetlensége - Jézus ezen kijelentésére „Amit tenni fogsz, tedd meg hamar!" - két húsvéthoz kötődő szokás lejegyzésére is alkalmat biztosít: a szegények megsegítését, illetve a húsvéti vacsorára való bevásárlás tényét. Ezzel a sajátos kronológia ismét megerôsítést nyer. ${ }^{8}$

\subsection{Az eucharisztia alapításáról szóló rész}

Mind Jézus tetteiból, mind az ó igehirdetéséból világos, hogy az asztalközösség milyen fontos szerepet töltött be nála, aki tökéletesen azt élte meg, amit hirdetett. ${ }^{9}$ Ennek a résznek a megértéséhez szükséges arra a tényre is figyelnünk, hogy az értelmezések sokféleségét nagyon gyakran a felekezeti hovatartozás határozza meg. Az utolsó vacsorát - a szinoptikusok leírását követve - a kutatók egy része húsvéti vacsorának tekinti, míg a többség ezzel szemben foglal állást az elsô század végén keletkezett János evangélium alapján.

Az utolsó vacsorára mint húsvéti vacsorára tekintők érvei az alábbiakban foglalható össze: 1. Az utolsó vacsora este történt és belenyúlt az éjszakába ${ }^{10}$, ahogyan

\footnotetext{
${ }^{5}$ Vö. da Spinetoli, Ortensio, Máté az egyház evangéliuma, Szeged 1998, 701-705.

${ }^{6}$ Vö. Ernst, Josef, Lukács Egy teológus portréja, Győr 2010, 62.

${ }^{7}$ Vö. da Spinetoli, Ortensio, Lukács a szegények evangéliuma, Szeged 2001, 678.

${ }^{8}$ Vö. Schwank, Benedikt, János, Szeged 2001, 428-433.

${ }^{9}$ Vö. Egger-Wenzel, Renate - Ernst, Michael (szerk.), Herders Neues Bibellexikon, Freiburg 2008, 3 .

${ }^{10}$ Vö. Mk 14,17; Jn 13,30
} 
az kötelező volt a húsvéti vacsorára vonatkozóan. Abban a korban a zsidók rendszerint délután fogyasztották a napi fó étkezésüket. 2. A húsvéti vacsora szimbolikus jelleggel bíró vacsora volt, amely éppen ezért eltért a hétköznapok során fogyasztott ételektől. A kenyértörést megeloozte az előétel, amely az Istentől kapott szabadságot szimbolizálta. ${ }^{11}$ 3. Ahogy Jn 13,29-ben is olvashatjuk, a kivonulás éjszakáján szokás volt a szegények megsegítése. 4. A húsvéti vacsorán kötelezô volt a bor fogyasztása, mint ahogy az az utolsó vacsorán történt. 5. Mk 14,26 és Mt 26,30 is megemlíti, hogy a vacsorát egy himnusszal fejezték be, ami könnyen azonosítható a 114. vagy 115-118. zsoltárból álló hallél imádság második részével, ami a húsvéti vacsora befejezô része volt. 6. Utolsó érvként sorolható fel az utolsó vacsora húsvéti vacsorával való azonosítására, hogy Jézus kenyér és bor felett elmondott szavait valószínúleg a kivonulás haggadája ihlette, amely során a házigazda elbeszélte a kivonulás történetét, miközben elmagyarázta az ott fogyasztott étel-ital szimbolikus jelentését is.

Az ezt a véleményt és érveléssort ellenzôk a következóket állítják: A felsorolt érvek jó része egy ünnepélyes zsidó étkezés jellemzői is lehetnek. Továbbá: Jeruzsálem és a hallél említése csupán redakciós része az elbeszélésnek. 2. Az éjszakai étkezés oka lehetett az is, hogy Jézus elfogatása előtt biztonsági okból gyưltek össze éjszaka, így nem feltétlenül a húsvéti vacsora megülése lehet az éjszakai találkozás oka. 3. A húsvéti vacsora megülése családi ünnep volt, amelyen nemcsak a férfiak, hanem a nôk és gyerekek is részt vettek. Ez utóbbiak közül épp a legkisebb kérdezte a családfőt, mit is ünnepelnek aznap. A családi ünneppel szemben Jézus csak a tizenkét apostollal osztotta meg ezt a vacsorát, csupán férfiakból álló közösséggel. Jézust sem mutatják be az evangéliumok családfóként, aki az utolsó kehelyre mondott áldást rendszerint egy megtisztelt férfi vendég részére engedte át. 4. A húsvéti vacsorát nagyon részletesen szabályozó isteni parancsnak megfelelôen élesztố nélküli kenyeret kellett fogyasztaniuk ezen az éjszakán. Ennek a görög megfelelôje a görög azyma fônév lenne, ehelyett az artos fơnevet találjuk, ami kenyeret jelent. 5. Nem találhatunk egyik újszövetségi leírásban sem említést a húsvéti bárányról, sem a keserú fưrôl. 6. A húsvéti vacsorán mindenkinek saját boros kupája volt, míg az evangéliumi elbeszélés egyetlen, közös kehelyrôl beszél. 7. A Mk 14,1-2 helyes kronológiája (két nappal a kivonulás és a kovásztalan kenyér ünnepe elôtt) szemben áll Jézus letartóztatásának késóbbi leírásával (Mk 14,43-50). 8. Több olyan esemény is van, amely valószínúleg nem történhetett meg ezen az ünnepi napon (Niszán hó 15-én): fegyverviselés (vö. Mk 14,43; Mt 26,47; Mk 14,47-49; Mt 26,51-55), a szanhedrin gyúlése és Jézus halálra ítélése, Cirenei Simon mezôról érkezése, Jézus temetése, valamint a halotti gyolcs megvásárlása. 9. Jézus utolsó vacsorája apostolaival nem egy húsvéti vacsora volt, hanem vagy egy kíddús vagy egy habúrá, esetleg egy ünnepélyes zsidó étkezés. Sok közös vonás figyelhetô meg az esszénusok ünnepi étkezése és az utolsó vacsora között. De a legvalószínúbb az, hogy a húsvéti vacsora egy tódá volt, vagyis egy olyan liturgikus étel, amelyet az imádság és az igehirdetés szavai követtek, de nem szerepelt ebben feltétlenül

\footnotetext{
${ }^{11}$ Vö. Mk 14,20; Mt 26,23; Jn 13,26
} 
áldozat. 10. Kérdésként merült fel, hogyan történhetett meg az, hogy az évenként egyszer megült húsvéti vacsorát az Egyház rendszeresen megünnepelte.

Természetesen azok a kutatók, akik fenntartják az utolsó vacsora húsvéti vacsorával való azonosságát, igyekeztek ezeket az ellenvetéseket megválaszolni. 1. Kétségtelen, hogy az artos görög fớnevet a kovásztalan kenyérre is lehet használni, mint ahogy az is, hogy ezek az evangéliumi elbeszélések a korai egyház kultikus megfogalmazását használják. Innen pedig egyértelmú, hogy az volt fontosabb, amit Jézus mondott és nem az, hogy mi található a húsvéti vacsora előírásában. 2. A felsorolt események (fegyverviselés, a szanhedrin gyúlése és Jézus halálra ítélése, Cirenei Simon mezốról érkezése, Jézus temetése, valamint a halotti gyolcs megvásárlása) mind megtörténhettek ünnepnapon: katonák és magánszemélyek is saját maguk megvédésére viselhettek fegyvert szombaton és ünnepnapokon is. A Második Törvénykönyvben felsorolt módon, néhány kivételes esetben, (mint például hamis próféták esetén) megengedték a kivégzést is ünnepnapon. Ráadásul Jézus korában a kivégzés a rómaiak fenntartott joga volt. Cirenei Simon mezôról érkezése nem jelenti azt, hogy ünnepnapon dolgozott, hiszen még elég korán volt ahhoz, hogy napi munkáját befejezhette volna. Valószínúbbnek tûnik, hogy - amennyiben zsidó volt - a templom reggeli szolgálatára igyekezett. Általános értelemben szombatokon és ünnepnapokon tilos volt adni-venni, de ezen törvényi előírás alól is voltak kivételek, amelyek a valós szükséghelyzetekhez tartoztak, mint például a halál esete. 3. A kiddús egy olyan áldó imádság, amelyet a házigazda mondott egy pohár bor felett, amit aztán ő és vendégei fogyasztottak el a szombati vagy egy ünnepi étkezés kezdetén. Az előbbi mindig pénteken naplemente után és sohasem elótte történt. A habúrá vallási közösséget jelent, amely azonban nem merült ki csupán kultikus eseményekben, hanem hozzátartozott a mózesi törvény betartása, az adó megfizetése, különleges rítusok betartása, a körülmetélkedés, elkötelezettség, stb. Jézus és a tanítványai azonban nem alkottak ilyen közösséget. 4. Nem lehet kétséget kizáróan bizonyítani, hogy az utolsó vacsorára az esszénus étkezés hatással lett volna, hiszen a fellelhető három forrás eléggé hiányos. Fontos eltérés a kettő között, hogy az esszénusok naponta kétszer fogyasztották az ételt és sohasem este. $\mathrm{Az}$ is biztos, hogy nôk ott nem lehettek jelen, míg az utolsó vacsora esetén ezt nem lehet kizárni. Az áldások, imádságok és tanítások sorrendjei sem egyeznek meg a kettôben. Az esszénus étkezésnél bárki is volt jelen, mindig egy pap adta az áldást. Abban sem lehetünk biztosak, hogy az esszénusok fogyasztottak bort ezeken az étkezéseken. Viszont azt, hogy az utolsó vacsora tódá lenne, valós lehetôségként kell számon tartani.

Arra a kronológiai eltérésre, ami az utolsó vacsora idôpontjára vonatkozóan a szinoptikus evangéliumok és János evangéliuma között fennáll, nagyon sok magyarázat született: Jézus megelólegezte a kivonulás ünnepét; több idôpont létezett a húsvét ünnepére, mert a galileaiak nem tudták pontosan meghatározni a telihold idejét; a jeruzsálemi zsidók késóbbre helyezték a húsvétot, hogy ne legyen két egymást követô pihenônap. Billerbeck két naptárra vezette vissza a kérdést, amelyek a farizeusok és szadduceusok vitája miatt jöttek létre és a Holdnaptár és a Naphoz 
igazodó naptár közötti különbség kiegyenlítése miatt további napok hozzáadását igényelte. A XX. század közepe táján megjelent tanulmánysorozatban Annie Jaubert francia kutató szintén két naptárról beszél. Az egyik a hivatalos, papi naptár, amelyrôl a héber nyelven írt, Kr. e. 2. századból származó Jubileumok könyve tudósít. Mivel egy év ebben a naptárban 364 napból, négy 91 napos negyedévból áll, a liturgikus ünnepek minden évben ugyanarra a napra esnek: Niszán hó 15-e minden évben szerdára esik, így a pászka-vacsorára kedden este, naplemente után került sor. ${ }^{12}$ A másik naptár a Qumránban és talán Galileában is használt Naphoz igazodó naptár. János a hivatalos jeruzsálemi szerint, míg a szinoptikusok a qumráni szerint mutatják be az eseményeket. Jaubert véleményét látszólag meggyőző érvelése ellenére sem sokan fogadják el. Hoehner azt feltételezte, hogy kétféle időszámítás létezett attól függóen, hogy a napot estétől estig vagy napkeltétól napkeltéig számolták. Ez alapján magyarázza azt, hogy Jézus egy nappal korábban, Niszán hó 14-én tartotta volna az utolsó vacsorát, ami nem valószínú. Leaney szerint János evangéliumának történeti dokumentum jellegét sokan túlhangsúlyozzák, noha a négy evangélium közül ez rendelkezik a legnagyobb teológiai hangsúllyal. Jézust az Isten bárányaként mutatja be (vö. Jn 1,29), ami erôsen hozzájárul ahhoz, hogy a szinoptikusokkal szemben ne azonosítsa az utolsó vacsorát a húsvéti vacsorával: Jézust éppen abban az órában adják át keresztre feszítésre, amikor a húsvéti bárányt a templomban feláldozzák (vö. Jn 19,14). Betániai megkenésére is akkor került sor, amikor a húsvéti bárányt kiválasztották (vö. Jn 12,1), valamint a húsvéti bárányra vonatkozó előírás is beteljesedett Jézus keresztre feszítésekor: „Mert ezek azért történtek, hogy beteljesedjék az Írás: »Csontját ne törjék össze $\ll$. (vö. Jn 19,36; Kiv 12,46; Szám 9,12) ${ }^{13}$

Az utolsó vacsora idôpontjára vonatkozó sok érv és ellenérv között nagyon nehéz eligazodni, s annak ellenére, hogy János evangéliuma készült el a legkésóbb (a Kr. u. 1. század végén), a szinoptikusok és János közül választva a legfiatalabb apostol múvét kell a fellelhetô források alapján hitelesnek tekintenünk. John P. Meier Jézusról szóló könyvében ${ }^{14}$ nagyon alapos értékelést követően jutott erre a következtetésre. Az mindenképpen biztos, hogy János pontosan tudósított arról, hogy a zsidó hatóságok Jézus Pilátus elótti pere előtt még nem fogyasztották el a húsvéti vacsorát, s ezért tisztának kellett maradniuk, így ók nem is mentek be Pilátushoz. Az is kétségtelen, hogy nem az ünnepen, hanem az elótte való napon feszítették keresztre Jézust, pontosan azon a napon, amikor a húsvéti bárányt a templomban leölték. Meier sem tudott azonban meggyốzó választ adni arra, hogy a szinoptikusok miért beszéltek pászka-vacsoráról. Azt azonban el lehet fogadni tôle, hogy a kétféle hagyomány abban megegyezik, hogy a vacsora jellegét nem a pászka határozta meg. Mi miatt alakulhatott ki mégis igen korán az utolsó vacsora húsvéti

\footnotetext{
${ }^{12}$ Vö. Ratzinger, Joseph XVI. Benedek, A názáreti Jézus Második rész A jeruzsálemi bevonulástól a feltámadásig, Budapest 2011, 88-89.

${ }^{13}$ Freedman, David Noel (szerk.), The Anchor Bible Dictionary Volume 4. K-N, New York 1992, 234-237.

${ }^{14}$ Vö. Meier, J.P., Marginal Jew. Rethinking the Historical Jesus I. The Roots of the Problem and the Person, New York 1991, 372-433.
} 
jellege? Meier válasza egyszerú, de lényegre törô: „Jézus tudta, hogy hamarosan meghal. Tudta, hogy a pászkavacsorát már nem költheti el. Mindennek teljes tudatában övéit egészen különleges utolsó vacsorára hívta meg, amely nem tartozott egyetlen zsidó rítushoz sem. Az ó búcsúja volt ez, amelyen valami újat adott, önmagát ajándékozta igazi bárányként, és ezzel megalapította a saját pászkáját."15

Az új pászka megértéséhez - amelyben a régi teljes értelmet nyert - néhány ószövetségi témát is röviden át kell tekintenünk.

\subsubsection{A szövetség}

Az egyiptomi szolgaságból népét kivezető Isten a Sínai hegynél szövetséget kötött velük. Saját kezdeményezéséból és akaratából választotta ki azt a népet, amelytôl azt kérte, hogy csak Ôt imádja, csak neki szolgáljon, rajta kívül más Istent ne ismerjen. Miután a nép beleegyezett az Isten szövetségi akaratába, ünnepélyes szertartás végeztek, melynek során leölt bikák kiömlő vérének felét az oltárra öntötték - a kôoltár Istent jelképezte - a másik felével pedig a népet hintették meg, miközben Mózes ezeket a szavakat mondta: „Ez annak a szövetségnek a vére, amelyet az Úr megkötött veletek e szavak alapján!"16 Ez a szövetség biztonságot és alapot biztosított az izraelita nép minden tagjának, amelynek feltétele az volt, hogy ne térjen el a szövetségkötéskor vállalt dolgoktól.

\subsubsection{Az áldozat}

A Sínai hegyi szövetségkötés áldozati szertartás volt. Ez azonban nem egyedülálló, hiszen szinte az emberiség minden vallásában jelen van az istenségnek bemutatott áldozat. Az áldozatbemutatások célja sokszor az volt, hogy kielégítsék az istenek szükségleteit, lecsillapítsák haragját, esetleg az áldozatot bemutatók ,lefizessék" az isteneket. Ez előfordulhatott az izraeliták között is, de az izraelita vallás hivatalos képviselői ezt elutasították, mivel tisztában voltak azzal, hogy az Istennek nincs szüksége semmilyen dologra, amit az ember adhat neki. Az áldozati szertartás célja az, hogy az ember az áldozat, mint ajándék által kifejezze az Isten iránti önátadó szeretetét. A nép áldozatának elfogadása az Isten részéról csak a szövetségben érthetô meg. Izrael történetében a próféták sokszor figyelmeztették a választott népet, hogy az áldozataik teljesen hiábavalóak, ha azokat nem töredelmes és alázatos szívvel, jog és igazság szerint mutatják be az Úrnak. ${ }^{17}$

\subsubsection{Az áldozati lakoma}

Az áldozati szertartáshoz szinte mindig áldozati lakoma is társult. Ennek ,alapanyaga" az áldozati állat Istennek felajánlott és a papoknak járó rész maradéka,

\footnotetext{
${ }^{15}$ Ratzinger, op. cit., 91-92.

${ }^{16}$ Kiv $24,8 \mathrm{c}$

${ }^{17}$ Vö. Ám 5,21-24
} 
amelyet visszakapott a felajánló. Ez azonban már nem közönséges, hanem az Istentől visszakapott étel, amelynek elfogyasztása egységet, közösséget hozott létre az Isten és a felajánló között. A hétköznapi étkezés is óriási jelentôséggel bír az ember számára: külső energiaforrást, ételt kell igénybe vennie, hogy az élethez, az életben maradáshoz szükséges energiához jusson. Ugyanakkor az étkezés közösségi dimenzióval is rendelkezik, hiszen ha az embernek módjában áll, másokkal eszik.

\subsubsection{Az emlékünnep}

Az izraelita áldozati szertartások a sok hasonlóság mellett abban térnek el a pogány áldozati szertartásoktól, hogy azok az Isten kinyilatkoztatásával és tetteivel állnak kapcsolatban, amelyekkel az Isten megmutatta irántuk való szeretetét és irgalmát. A szertartások során ezeket az isteni tetteket és szavakat idézik emlékezetükbe. A legkiemelkedôbb példa erre az egyiptomi szolgaságból való szabadulásra emlékezés, a húsvéti bárány szertartása. Az ünnepet megeloozően Niszán hó 13. és 14. között az egész házat átkutatták, hogy a kovászos kenyeret megtalálják, amit ha 14-én 11-ig nem fogyasztottak el, akkor délben el kellett égetni. ${ }^{18}$ Niszán hó 14-én este a Templomban aznap feláldozott bárányt családonként fogyasztották el, emlékezve a szolgaság földjérôl való szabadulásra. A vacsora menete a következô volt: a családfő asztali áldását követően egy pohár bort ittak, majd kesernyés salátát fogyasztottak piros mártással, melynek szimbolikus értelme volt. A saláta a keserú szolgaságra, a piros mártás a piros téglákra emlékeztette óket, amelyet a kényszermunka során kellett készíteniük. Az emlékezést segítette még az események konkrét felidézése, amelyet a legfiatalabb gyermek azon kérdésére: „Mit jelent ez a szertartás?”, a családfő válaszolt meg a kivonulás eseményeinek felidézésével. A báránypecsenye emléke annak a báránylakomának, amelyet a tizedik csapás éjszakáján fogyasztottak az Isten angyala pusztításától megkímélt izraeliták. A kovásztalan kenyér pedig az idő rövidsége miatt megkeletés nélkül készített kenyér emléke, ugyanakkor a pusztai vándorlás mannájára is utal. A magyarázat után a 113. és 114. zsoltárral magasztalták az Isten, majd pedig ittak még egy pohár bort, aztán kezdték a lakomát. A családfố a kezébe vett egy kovásztalan kenyeret, mondott egy imát, legtöbbször a következó szavakkal: „Magasztaltassál, Urunk, Istenünk, a világ királya, aki megcselekszed, hogy a föld kenyeret teremjen."19 Ezt követően a házigazda megtörte a kenyeret, evett egy falatot és a többieknek is adott egy-egy falatot. A bárány és minden más étel elfogyasztása után a családfő poharát ismét megtöltötték borral, amelyet egy hálaadó ima után kiivott, mint ahogy mindenki más a sajátját. Végül a 115-118. zsoltár imádkozásával zárult az ünnepi lakoma. Ez a lakoma tehát az egyiptomi szolgaságból való megszabadulás emlékünnepe, amely során az Isten Izraelt megmentô tetteire való emlékezés mellett annak a megvallására is sor került, hogy ez az Isten az, akinek a támaszára a jelenben is igényt tartanak. Az ősökkel kötött szövetség alapján az Isten irgalma és húsége a biztosí-

\footnotetext{
${ }^{18}$ Vö. Haag, Herbert (szerk.), Bibliai lexikon, Budapest 1989, 660.

${ }^{19}$ Cserháti Sándor, Pál apostolnak a korinthusiakhoz irt elsố levele Fordítás és magyarázat, Budapest 2008, 510.
} 
téka ezen kérés meghallgatásának. Sok imádság ezt az alapmotívumot tartalmazza: az ősökre való tekintettel, a nekik tett ígéretek alapján az Isten ne számítsa be az utódok vétkét és legyen irgalmas velük. Nemcsak a múlt és a jelen, hanem a jövô is hozzátartozik az emlékünnep lényegéhez: az emlékünnep célja, hogy siettesse a messiási kor eljövetelét.

\subsubsection{Az új szövetség}

A Sínai hegynél kötött szövetség két alanya nem egyenrangú: az izraelitáknak üdvtörténetük során meg kellett tapasztalniuk, hogy az Isten húségével szemben az isteni jótéteményekre nagyon gyakran hútlenséggel, törvényszegéssel válaszoltak. A prófétai figyelmeztetések, mint pl. Jeremiás korsó-törése, Ezekiel levágott hajfürtjeinek elégetése, mind a büntetés bekövetkeztét erôsítették meg. Akkor, amikor Jeruzsálem elesett, az Isten prófétáin keresztül vigasztalta a népet: egy új és örök szövetséget fog kötni velük, amelyet az ember nem törhet meg. Ekkor az Isten megbocsátja bûnüket, új szívet ad nekik, saját Lelkét helyezi beléjük, hogy mindnyájan megismerjék az Urat. ${ }^{20}$

\subsubsection{Az Úr szolgája}

Deutero-Izajás négy énekben mutatta be azt a szolgát, aki prófétai és királyi vonásokat ötvözve már anyja méhétól fogva kiválasztott és Isten Lelke tölti el. A maga bûntelen volta ellenére „, ... ốt a mi vétkeinkért szúrták át, a mi búneinkért törték össze; a mi békességünkért érte fenyítés, és az ő sebe által gyógyultunk meg."21 Ô az Isten üdvösségének közvetítője minden nemzetek számára. Sok magyarázat látott már napvilágot arra vonatkozóan, hogy a próféta eredetileg ki(k)re gondolt a szenvedô szolgáról jövendölve. Az azonban kétségtelen, hogy az ôsegyház szilárd meggyőződése szerint ez a szolga nem más, mint Jézus Krisztus.

\subsubsection{Velünk az Isten}

Az önmagát kinyilatkoztató Isten transzcendens, ugyanakkor felfoghatatlan módon közel is van az emberhez. A kinyilatkoztatás sátrában, majd a jeruzsálemi templomban lakó Istent azonban mégsem lehet megfogni. Krisztus szerette az Isten házát, de elutasította azt a régi áldozati kultuszt, amely az elszertartásodozás és a hamis külsôségekben való bizakodás veszélyének volt alanya. Új módon van velünk az Isten, nem egy építményben, hanem az Isten-ember Jézus Krisztusban. Ố az Immánuél, a „Velünk az Isten”, aki megváltó halálával megnyitotta számunkra az Édenkert ajtaját. ${ }^{22}$

\footnotetext{
${ }^{20}$ Vö. Jer 31,31-34

${ }^{21} \mathrm{Iz} 53,5$

${ }^{22}$ Vö. Nemeshegyi Péter, „Ezt cselekedjétek az én emlékezetemre..” Az eukarisztia teológiája, Szeged 1994, 13-23.
} 


\subsubsection{A szöveg története}

Az eucharisztia alapításának szavait négy helyen találhatjuk az Újszövetségi Szentírásban: mindhárom szinoptikus evangéliumban és az elsô Korintusiakhoz írt levélben. Az eltérô szövegeket két csoportra oszthatjuk. Az egyikbe a Máté és Márk evangéliumában található szöveg tartozik, míg a másikba Lukács evangéliuma és Pál apostol levele. A hasonlóság, az ünnepélyes formula arra enged következtetni, hogy az ôsegyház liturgikus gyakorlatában jelen volt már, amikor írásba foglalták. Ezt erôsíti meg az a tény is, hogy Pál azt írja, hogy „az Úrtól” kapta, amit átadott nekik. Itt nem magán kinyilatkoztatásra, hanem egyházi hagyományra kell gondolnunk, mivel a nemzetek apostolától függetlenül keletkezett iratokban is megtalálhatók. A Lukáccsal való azonosság onnan származik, hogy Pál apostol abból a szíriai Antióchiában élô keresztény közösségból indult missziós utakra, amelyból Lukács evangélista származott. Lukács és Pál szövege nem függ egymástól, s mindkettoon érezhető, hogy a Jézus korában beszélt hétköznapi nyelvból, arámból készült fordítások, amelyek Antióchiában az úrvacsora-szövetség típus 40-es években használt formájának tanúi. Márk szövege független ettôl a két szövegtől, viszont Máté szövege Márkén alapszik. ${ }^{23}$ A négy szöveg hasonlóságának oka az utolsó vacsora elbeszélésének Krisztus feltámadása és mennybemenetele utáni továbbadása arám nyelven.

A négy szövegváltozat egyike sem egyezik meg a másikkal szó szerint. Lényegileg mind magában hordozza a test és vér külön történő említésével a Jézus erôszakos halálára való utalást. A sóma (héber básár, arám bisrî) nem csak a testet jelenti, hanem az egész embert. A vér (görög haima - héber dám) az élet hordozója, ami által az Isten az életet akarja adni az embereknek. Az ,értetek” kifejezés inkluzív értelmû - mint ahogy a „,sokakért” is -, azaz mindenki jelentéssel bír. Ezt erôsíti meg, hogy az emlékezetre vonatkozó, cselekvést kifejezố igét a folyamatos cselekvést, ismétlődést kifejezô imperativus praesens igealakban találhatjuk. Ezzel megegyező jelentéssel bír a Máté szerinti „egyétek”, amely lényegi részesedést jelöl.

\subsubsection{Az utolsó vacsora értelme}

Jézus a tanítványaival családként ült asztalhoz, ahol Krisztus volt a családfô. Eljött az „órája”, hogy ô, mint Úr és mindenki szolgája feláldozza az életét. Az „áldásmondás” és a „hálát adás” a kétféle szövegváltozatban ugyanarra utal: Jézus az Atyát magasztalta és nem a kenyeret áldotta meg. Majd megtörte és anélkül, hogy evett volna belőle, odaadta tanítványainak a következố szavakkal: „Vegyétek ez testem, mely értetek adatik. Ezt tegyétek emlékemként." Valószínú, hogy a maga teljességében nem fogták fel a tanítványok, mirôl is van szó, amikor a jézusi tanítást követôen a vörös borral teli kelyhet kezébe vette, Istent magasztaló imát mondott, majd anélkül, hogy ivott volna belőle a tanítványainak adta ezekkel a

\footnotetext{
${ }^{23}$ Lásd a két forrás elméletet, in Thorday Attila (szerk.) Jeromos Bibliakommentár II. Az Újszövetség könyveinek magyarázata, Budapest 2003, 29-41.
} 
szavakkal: „Ez a kehely az új szövetség véremben, mely sokakért kiontatik.” Halálát megjövendölve utalt egy új életben bekövetkező találkozásra.

\subsubsection{Közös estebéd Jézussal}

Nyilvános múködése során Jézus sokszor étkezett együtt másokkal. Nem a társadalom felsố rétege vagy a vallásos elit volt részese az asztalközösségének, hanem az általuk lenézett és megvetett emberek: vámosok, bünösök, mint pl. Zakeus. Az apostolok sem voltak tökéletes emberek, de Jézus mégis velük, a nyilvános múködés java részét vele át- és megélő apostolokkal osztotta meg az utolsó vacsorát. Annak ellenére, hogy a kereszttől elmenekültek, mégsem szakadt meg az asztalközösségük Krisztussal, amit elsősorban Lukács apostol jegyzett fel.

\subsubsection{Jézus, az Úr szolgája}

Az utolsó vacsorán végbevitt jézusi cselekedet szimbolikus, prófétai tett ${ }^{24}$, melynek során Jézus odaadja önmagát, életét. Az arám bisrî, „testem” szó ugyanis nemcsak húst jelent, hanem elsősorban a halandó embert is. A vörös bor szétosztása pedig vértanúságát jelzi, mely által a sokaság bünbocsánatban részesül. Az „adatik” és „kiontatik” igék passzív igenemú alakjai Istenre utalnak, mint végső okra. Jézus így vált az atyai szeretet végletekig elmenô kinyilatkoztatójává. Jézus ezzel a prófétai tettével magára vette az izajási „Úr szolgájának” szerepét, önként ajánlotta fel életét. Ahhoz, hogy Jézus maga új szövetséggé lehessen, ahhoz ki kellett ontania vérét az utolsó cseppig. Krisztus testének és vérének átadásakor nem azt mondta, hogy „nektek adom”, hanem azt, hogy „értetek adatik”, illetve „értetek kiontatik”. Jézus Atyához való áldozati visszatérése minden ember javára, értetek történik.

\subsubsection{Jézus a szövetségi áldozat}

A páli-lukácsi szöveggel szemben Márk és Máté szövege nemcsak az Úr szolgájának gondolatkörét tartalmazza, hanem a Kiv 24. fejezetében leírt mózesi szövetségi áldozatét is. Mózes azt mondta: „Ez a vér a szövetségé”, míg Jézus: „Ez vérem, a szövetségé." A birtokos személyrag különbsége jelzi azt, hogy itt már nem a bikák, az áldozati állatok, hanem Jézus vére által történik a szövetség megkötése. A márki „test” és „vér” szavak párhuzama utal az ószövetségi állatáldozatokra, melyek következtében a hívő emberek a szövetség kegyelmében részesülhettek.

\subsubsection{Jézus önmagát adja az újszövetségi áldozati lakoma ételeként- italaként}

Mind a négy szöveg alapján állítható, hogy Jézus nemcsak szimbolikus tettet akart végrehajtani, azaz megmutatni, hogy ô az Úr szolgája, hanem adni is akart a tanítványainak. Ez az apostolok számára teljesen természetes volt, hiszen ók is gyakran

\footnotetext{
${ }^{24}$ Vö. da Spinetoli, Ortensio, Lukács A szegénység evangéliuma, Szeged 2001, 672.
} 
fogyasztottak az áldozati állatokból. Tudták azt is, hogy ez azt jelenti, hogy az Isten asztalközösségének, a szövetség kegyelmének lettek részesei. Ám az ószövetségi áldozatokkal szemben itt már csak egyetlen egy áldozat van, maga Jézus. Jézus, amikor új szövetséget alapított, akkor az újszövetségi áldozat evése és ivása által akarta az újszövetség kegyelmében részesíteni a tanítványokat. Mivel ô az egyetlen áldozat, ezért kellett testét és vérét étellé és itallá tennie, amelyet - mint Isten Fia - sokszor bizonyított hathatós szava által valósított meg. Testévé lett a kenyér és vérévé a bor, mert az Isten Fia szólt. Ezeknek a szavaknak a kiejtése azonban igényli azt is, hogy teljesen altruista legyen, ne akarjon megtartani a maga számára semmit. Jézus nem a bonyolult jeruzsálemi szertartásokat, hanem a lehetô legegyszerúbb módot választotta az újszövetségi áldozat megvalósítására. Melkizedek alakjára emlékeztet, aki kenyeret és bort vitt Ábrahámnak és megáldotta ót. ${ }^{25}$ Családi vacsora ez, amelyen a mindenkinek kijáró kenyeret és bort veszi magához az Isten házanépe. Az apostolok akkor biztosan meglepödtek, amikor Jézus azt mondta: „Igyatok ebból mindnyájan, mert ez vérem.” A zsidóknak tilos volt vért inniuk, mert a vért az élet szállító eszközének tekintették, az élet ura pedig az Isten. Jézus azonban ezzel a tettével éppen azt akarta kifejezésre juttatni, hogy az új szövetségben az Isten életet ad nekünk, Krisztusban az ô saját életét. Jézus szentségi jelenléte a mi számunkra van jelen és nem elsôsorban a kenyérhez és borhoz viszonyuló jelenlét.

\subsubsection{Az újszövetség emlékünnepe}

Jézus nemcsak az utolsó vacsorán részt vett apostolait részesítette az újszövetség kegyelmében, hanem azokra is gondolt, akik majd az ô szavukra hinni fognak benne. Ezért mondta: „Ezt cselekedjétek az én emlékezetemre!” Bár ez a mondat nem szerepel a márki-mátéi szövegben, mégis joggal feltételezzük, hogy tudatában voltak ennek a krisztusi parancsnak. Az ósegyház nem merte volna ezt tenni, ha Jézus nem hagyta volna meg ezt nekik. Ahogy az ószövetség idején a húsvéti bárányvacsora emlékünnep volt, úgy lett az újszövetség emlékünnepe az Úr vacsorája. ${ }^{26}$ Ekkor több dologra emlékezünk: az Atya szeretetére, mely egyszülött Fiát adta értünk; a Jézus szeretetét is bizonyító megváltó halálra és feltámadására. Ugyanakkor nemcsak az Atyára és Jézusra emlékezünk, hanem kérjük az Atyát, hogy ô is emlékezzen meg a mi tökéletes embertársunkról, s rá való tekintettel legyen irgalmas hozzánk, hiszen Jézus az üdvösségünk egyetlen reménye és biztosítéka. ${ }^{27}$ Ennek az emlékünnepnek a legrégebbi elnevezése: „az Úr vacsorája”, ahol a Kyrios a feltámadt Krisztust jelzi. Másik elnevezése a „kenyértörés”, amelyet a kincsüket féltô hívek az Isten házanépéhez még nem tartozó emberek jelenlétében használ-

\footnotetext{
${ }^{25}$ Vö. Ter 14

${ }^{26}$ A görög ,emlékezni” ige különböző, a teljes Szentírásban előforduló jelentésárnyalatainak összefoglalásához lsd. Tessarolo A., Dizionario dei concetti biblici del Nuovo Testamento, Bologna 1986, 990-996.

${ }^{27}$ Kittel, Gerhard (szerk.), Theologisches Wörterbuch zum Neuen Testament Erster Band A- , Stuttgart 1953, 351-352.
} 
tak. Az örömmel megült kenyértörés, illetve a Krisztus halálát is magába foglaló Úr vacsorája ugyanazon valóság kifejezésére szolgál. Az újszövetség emlékünnepének múltat, jelent és jövoot magába foglaló dimenzióját Pál apostol így foglalja össze: „Mert amikor ezt a kenyeret eszitek, és ezt a kelyhet isszátok, az Úr halálát hirdetitek, amíg el nem jön."28

\section{Szent Pál tanítása az Úrvacsoráról}

Pál apostol minden levele alkalmi írás, amelyben a címzettek körében fennálló problémát igyekezett orvosolni. Valószínúleg efezusi tartózkodása során fejtette ki álláspontját a korintusiak körében kialakult helyzetról, amikor az eucharisztia alapításának szavait is lejegyezte. A korintusi egyházban az „erôsek” azt gondolták, hogy mindent szabad, pl. részt venni a pogány isteneknek bemutatott áldozati lakomán is. Mivel ezek az istenek nem léteznek, Pál azt megengedi, hogy a piacokon forgalmazott áldozati húsból vásároljanak és fogyasszanak, mivel a bálványoknak feláldozott húsra nem ragad semmilyen káros erô, de azt semmiképpen sem tartja jónak, hogy a korintusi keresztények közül néhányan a pogány barátaikkal együtt pogány isteneknek bemutatott áldozati lakomán vegyenek részt. Pál okfejtése az isteni kinyilatkoztatást egységes folyamatnak tekintve a zsidó nép pusztai búnbeesését és az azért járó büntetést elóképnek és figyelmeztetésnek tartja a jelen helyzetre is. Így a keresztény, ha visszatér korábbi, bünös életére, akkor pusztulás vár rá. Pál szerint a keresztény szentség nem mágia, hanem a krisztusi életre való képesítés forrása. Az Úr vacsorájával kapcsolatban kifejti: „Az áldás kelyhe, amelyet megáldunk, nem Krisztus vérében való részesedés? És a kenyér, amelyet megtörünk, nem Krisztus testében való részesedés? Mert egy a kenyér, s egy test vagyunk sokan, hiszen mindnyájan egy kenyérból részesülünk."29 Pál az eucharisztiát az elsô keresztények által használt, zsidó eredetû kifejezésekkel illeti: „áldás kelyhe” illetve „kenyérszegés”. A kenyérben és borban, mint Krisztus testében és vérében való részesedés által a keresztényben Krisztus él és ô Krisztusban. Ez azonban a keresztények egymással való viszonyát is jelzi: ugyanazt a kenyeret eszik. Ez a kenyér nem azért egy, mert az egész közösség egyetlenegy kenyérból eszik - ez több száz fő esetén elképzelhetetlen - hanem azért, mert az egyetlenegy Úr, azaz Jézus Krisztus testéból részesülünk. Pál apostol ebben a levélben kitér az eucharisztiával kapcsolatos másik korintusi problémára is: a szeretetlakomákon történt visszaélések miatt a „kenyértörés” megcsúfolásáról volt szó. Pál kifejti, hogy ezek a lakomák nélkülözik a szeretetet, mivel a gazdagok dôzsölnek, a szegények pedig éheznek, nem valósul meg körükben a krisztusi szeretet, a Krisztust követő közösségi élet. ${ }^{30}$ Ezért Pál így figyelmezteti ôket: „Aki tehát méltatlanul eszi a kenyeret, vagy issza az Úr kelyhét, vétkezik az Úr teste és vére ellen. Vizsgálja meg tehát az ember

\footnotetext{
${ }^{28} 1$ Kor 11,26

${ }^{29} 1$ Kor $10,16-17$

${ }^{30}$ Vö. Freedman, David Noel, The Anchor Bible Dictionary Volume 5. O-Sh, New York 1992, 667.
} 
önmagát, és úgy egyék e kenyérból és igyék a kehelyből, mert aki úgy eszik és iszik, hogy nem különbözteti meg a testet, saját ítéletét eszi és issza."31 A nemzetek apostola a korintusiak körében előforduló nagyszámú betegség és haláleset okát is ebben látja. Tipikus páli megvilágításba kerül tehát az evangéliumokban megfigyelt tanítás az utolsó vacsoráról: az Úr halálát hirdeti ez a vacsora, mely a hívekre árasztja üdvözítő erejét. A Krisztus testében és vérében való részesedés által a hívek Krisztus testévé válnak. Ennek következménye, hogy élő hittel és szeretettel kell élniük egészen addig a napig, amíg az Isten lesz minden mindenben. ${ }^{32}$

\section{Befejezés}

Az utolsó vacsora elbeszélése két fontos eseményt mutat be: Jézus elárulásának kijelentését illetve az eucharisztia megalapítását. Függetlenül attól, hogy az utolsó vacsora valójában egybeesett-e a zsidó pászka ünneppel vagy sem, az kétségtelen, hogy Jézus Krisztus saját pászka ünnepéról van szó. A vacsora során a Vele legszorosabb, legközvetlenebb kapcsolatban álló tizenkét apostol a kenyérben és borban az ô testét és vérét vette magához, mert az Isten szava hathatós szó, megvalósítja azt, amit kijelent. Jézus kinyilvánította, hogy önként adja oda az életét minden emberért, annak az új szövetségnek a keretében, amely mindenkinek biztosítja az üdvösség lehetôségét.

\section{Irodalomjegyzék}

Cserháti Sándor (2008): Pál apostolnak a korinthusiakhoz írt elsô levele Fordítás és magyarázat. Budapest, Luther Kiadó.

da Spinetoli, O. (2001): Lukács a szegények evangéliuma. Szeged, Agapé Kft. Ferences Nyomda és Könyvkiadó.

da Spinetoli, O. (1998): Máté az egyház evangéliuma. Szeged, Agapé Kft. Ferences Nyomda és Könyvkiadó.

Dér Katalin - Jorsits Attila (2011): Beavatás Márk evangéliuma. Budapest, Kairosz Kiadó.

Egger-Wenzel, R. - Ernst, M. (szerk.) (2008): Herders Neues Bibellexikon. Freiburg, Verlag Herder.

Ernst, J. (2010): Lukács Egy teológus portréja. Győr, Kairosz Kiadó.

Freedman, D.N. (szerk.) (1992): The Anchor Bible Dictionary Volume 4. K-N.

New York, Doubleday.

Freedman, D.N. (szerk.) (1992): The Anchor Bible Dictionary Volume 5. O-Sh.

New York, Doubleday.

Gnilka, J. (2000): Márk. Szeged, Agapé Ferences Nyomda és Könyvkiadó.

Haag, H. (szerk.) (1989): Bibliai lexikon. Budapest, Szent István Társulat Az

\footnotetext{
${ }^{31} 1$ Kor $11,27-29$

${ }^{32}$ Vö. Nemeshegyi, op.cit., 24-50.
} 
Apostoli Szentszék Könyvkiadója.

Kittel, G. (szerk.) (1953): Theologisches Wörterbuch zum Neuen Testament Erster Band A- . Stuttgart, Verlag von W. Kohlhammer.

Meier, J.P. (1991): Marginal Jew. Rethinking the Historical Jesus I. The Roots of the Problem and the Person. New York, Doubleday.

Nemeshegyi Péter (1994): „Ezt cselekedjétek az én emlékezetemre..” Az eukarisztia teológiája. Szeged, Agapé Kft. Ferences Nyomda és Könyvkiadó.

Ratzinger, J. XVI. Benedek (2011): A názáreti Jézus Második rész A jeruzsálemi bevonulástól a feltámadásig. Budapest, Szent István Társulat Az Apostoli Szentszék Könyvkiadója.

Schwank, B. (2001): János. Szeged, Agapé Kft. Ferences Nyomda és Könyvkiadó. Tessarolo, A. (1986): Memoria, In: Coenen, L. - Beyreuther, E. - Bietenhard,H. [szerk.], Dizionario dei concetti biblici del Nuovo Testamento. Bologna, Edizioni Dehoniane Bologna. 990-996.

Thorday Attila (szerk.) (2003): Jeromos Bibliakommentár II. Az Újszövetség könyveinek magyarázata. Budapest, Szent Jeromos Katolikus Bibliatársulat.

Gánicz Endre teológus, Szent Atanáz Görög Katolikus Hittudományi Főiskola, Szentírástudományi Tanszék 